This is the author's manuscript for publication. The publisher-formatted version may be available through the publisher's web site or your institution's library.

\title{
Non-target effects of chlorantraniliprole and thiamethoxam on Chrysoperla carnea when employed as sunflower seed treatments
}

Pablo C. Gontijo, Valéria F. Moscardini, J. P. Michaud and Geraldo A. Carvalho

How to cite this manuscript

If you make reference to this version of the manuscript, use the following information:

Gontijo, P. C., Moscardini, V. F., Michaud, J. P., \& Carvalho, G. A. (2014). Non-target effects of chlorantraniliprole and thiamethoxam on Chrysoperla carnea when employed as sunflower seed treatments. Retrieved from http://krex.ksu.edu

\section{Published Version Information}

Citation: Gontijo, P. C., Moscardini, V. F., Michaud, J. P., \& Carvalho, G. A. (2014). Non-target effects of chlorantraniliprole and thiamethoxam on Chrysoperla carnea when employed as sunflower seed treatments. Journal of Pest Science, 87(4), 711-719.

Copyright: @ Springer-Verlag Berlin Heidelberg 2014

Digital Object Identifier (DOI): doi:10.1007/s10340-014-0611-5

Publisher's Link: http://link.springer.com/article/10.1007\%2Fs10340-014-0611-5

This item was retrieved from the K-State Research Exchange (K-REx), the institutional repository of Kansas State University. K-REx is available at http://krex.ksu.edu 


\section{Non-target effects of chlorantraniliprole and thiamethoxam on Chrysoperla carnea when employed as sunflower seed treatments}

\section{Pablo C Gontijo, ${ }^{\mathrm{a}, \mathrm{b}}$ Valéria F Moscardini, ${ }^{\mathrm{a}, \mathrm{b}}$ JP Michaud ${ }^{\mathrm{b} *}$ and Geraldo A Carvalho ${ }^{\mathrm{a}}$}

aDepartment of Entomology, Federal University of Lavras, Lavras, Minas Gerais, Brazil

${ }^{b}$ Department of Entomology, Kansas State University, Agricultural Research Center-Hays, Hays, Kansas, USA

*Corresponding author: JP Michaud, 1232 240 th Ave, Hays, KS, 67601. Email: jpmi@ksu.edu

\section{Key Message}

- Sunflower extrafloral nectar is utilized by many beneficial insects and is a potential route of exposure to systemic insecticides applied as seed treatments

- Both chlorantraniliprole and thiamethoxam adversely impacted Chrysoperla carnea adults when they fed on extrafloral nectar of seedlings grown from treated seed

- Both insecticides reduced adult survival and fecundity, especially thiamethoxam, and offspring of chlorantraniliprole-exposed adults had lower survival than those of controls

\section{Abstract}

The use of systemic insecticides as seed treatments has raised concern about the possible impacts of these products on natural enemies. This study assessed the effects of sunflower seed treatments with chlorantraniliprole and thiamethoxam on Chrysoperla 
carnea by exposing larvae and adults to sunflower stem segments grown from treated seeds and the nectar secreted by their extrafloral nectaries. Confinement of larvae with stem segments for their entire developmental period had no effect on their survival or any life history parameter, except that the sex ratio of resulting adults was lower in the thiamethoxam treatment than in

chlorantraniliprole. However, when adult pairs of $C$. carnea were exposed to treated stem segments during their maturation period, their subsequent survival and fecundity was significantly reduced by both materials, with thiamethoxam reducing median survival $\left(\mathrm{LT}_{50}\right)$ and fecundity to a greater degree than chlorantraniliprole. Insufficient offspring were obtained from adults exposed to thiamethoxam to permit assessment of their fitness, but the offspring in the chlorantraniliprole-exposed adults had reduced larval survival relative to controls. The greater impact of seed treatments on adult lacewings may be partly attributable to their greater consumption of extra-floral nectar. Our results indicate that seed treatment with systemic insecticides can cause negative effects on beneficial insects, potentially disrupting their population dynamics, and should not be assumed compatible with biological control and IPM simply because this mode of application limits direct exposure.

Keywords Extrafloral nectar, systemic insecticides, IPM, green lacewings, environmental risk assessment

\section{Author contribution statement}

JPM and GAC designed the experiments.

PCG and VFM conducted the experiments and analyzed the data.

PCG, VFM and JPM wrote the paper and GAC edited the final draft.

\section{Introduction}


The potential for non-target effects of systemic insecticides when used as seed treatments has recently become a topic of interest and controversy (Sanchez-Bayo et al. 2013). Seed treatments are now widely employed as a prophylactic control measure to protect crops against seed and seedling pests (Bradshaw et al. 2008; Strausbaugh et al. 2010). Their use has, to some extent, reduced the need for broadcast applications of insecticides to ensure stand establishment, thus lowering pesticide exposure for non-target organisms (Hull and Beers 1985; Albajes et al. 2003; Cloyd and Bethke 2011). However, research has shown that seed treatments may also pose a risk to beneficial organisms via less obvious routes of exposure, causing both lethal and sublethal effects (Li et al. 2012). Sublethal effects, in particular, are easily overlooked and yet may have considerable impact on natural enemy population dynamics and the level of ecosystem services contributed by these insects (Desneux et al. 2007; He et al. 2012; Biondi et al 2012a; Biondi et al. 2013; Planes et al. 2013)

Systemic insecticides are characterized by low lipophilicity, typically exhibiting an octanol-water partition coefficient (log Poct) below 40 (Cloyd and Bethke 2011) which facilitates their translocation in plant tissues. Residues of such insecticides can be translocated to various plant parts (Dively and Kamel 2012; Goulson 2013). For example, residues of imidacloprid have been found at $13 \mathrm{ppb}$ in sunflower pollen following its application as a seed treatment (Laurent and Rathahao 2003). Chlorantraniliprole and thiamethoxam represent two systemic insecticides used in seed treatments, belonging to two different groups, diamides and neonicotinoids, respectively. Chlorantraniliprole acts as a ryanodine receptor modulator to block insect muscle contraction (Lahm et al. 2007). In contrast, thiamethoxam is a neonicotinoid insecticide that targets nicotinic acetylcholine receptors in the central nervous system of insects, causing overstimulation at low concentrations, and receptor blockage, paralysis and death at higher concentrations (Tomizawa and Casida 2005). Furthermore, thiamethoxam breaks down into clothianidin, a highly active openchain neonicotinoid with somewhat different properties (Ohkawara et al. 2002; Schwarz et al. 2002) which may contribute to its activity in both plants and insects (Benzidane et al. 2010). Both classes of materials pose potential hazards to non-target organisms because of their ability to contaminate pollen, floral and extrafloral nectar (Lahm et al. 2009). 
Pollen and nectar, both floral and extrafloral, are important resources for many natural enemies of insect pests (Wackers et al. 2007; Lundgren 2009; Choate and Lundgren 2013), and thus constitute potential routes of exposure to systemic insecticides for natural enemies and pollinators (Cloyd and Bethke 2011; Stoner and Eitzer 2012; Easton and Goulson 2013). However, floral nectar and pollen are only produced by mature plants in reproductive stages, whereas extrafloral nectar may be produced in much earlier stages of plant development when systemic materials applied as seed treatments are present in plant tissues at much higher concentrations. In sunflower, nectaries occur first on the main stem above the cotyledons, and henceforth on all stems and leaf petioles, so they are present from the time the first pair of true leves expands, about two weeks after germination (JPM, personal observation). The vast majority of commercial sunflower seed in the USA is now sold with a factory-applied seed treatment.

Among many beneficial predators in agriculture, green lacewings, Chrysoperla spp. (Neuroptera: Chrysopidae), stand out as cosmopolitan species that are easily reared in the laboratory, widely commercialized in augmentation biological control programs, and highly valued for conservation in IPM systems for field crops (Albuquerque et al. 1994; Pappas et al. 2011). Lacewings are polyphagous predators that contribute to natural control of many pests of economic importance in agriculture (New 1975; Principi and Canard 1984; Stelzla and Devetak 1999). The larvae of Chrysoperla carnea (Stephens) feed on a wide range of small, softbodied arthropods with a preference for aphids (Principi and Canard 1984). Non-prey foods such as honeydew, floral and extrafloral nectar, and pollen can be important resources for chrysopids in both larval (Downes 1974) and adult (Venzon et al. 2006) stages. Limburg and Rosenheim (2001) showed that extrafloral nectar was an important food source for neonate lacewing larvae on cotton and that its consumption increased as the availability of aphid prey declined. Patt et al. (2003) showed that larvae of $C$. carnea used the carbon present in sugar to supplement their diet and enhance their growth and development. Adults of $C$. carnea are not predaceous, feeding only on extrafloral and floral nectar, pollen, and honeydew (Principi and Canard 1984; Hagen 1986) and provision of a nectar source is known to increase fecundity and extend adult longevity in this species (Gurr et al. 2004). In the central plains of the USA, $C$. carnea adults are among a wide range of beneficial insects that colonize sunflowers during dry 
summer months (Royer and Walgenbach 1991) and can often be observed exploiting the abundant extrafloral nectar that these plants produce (JPM, personal observation).

Given the potential for contamination of sunflower extrafloral nectar with chlorantraniliprole and thiamethoxam when applied as seed treatments, the objective of the present study was to assess whether either material would affect key life history parameters of $C$. carnea when both larvae and adults were exposed to sunflower seedlings grown from treated seed.

\section{Materials and methods}

Insects

Adults of $C$. carnea were collected from a sorghum field at the Agricultural Research Center-Hays in Hays, Kansas, USA $\left(38^{\circ} 51^{\prime} 3114^{\prime \prime} \mathrm{N} 99^{\circ} 20^{\prime} 1086^{\prime \prime W}\right)$. The lacewings were placed in a plastic container (14.0 cm diam x $19.0 \mathrm{~cm}$ ht) covered with an organdy mesh screen held in place with a rubber band. The stock colony and all bioassays were held in a climate-controlled growth chamber set to $24.0 \pm 1.0{ }^{\circ} \mathrm{C}, 42 \pm 5 \% \mathrm{RH}$ and a photoperiod of 16:8 (L:D). Adults in the stock colony were provisoned every $48 \mathrm{~h}$ with an artificial diet composed of honey and brewer's yeast (1:1) smeared on two parafin wax strips and water on a piece of sponge, both refreshed every $48 \mathrm{~h}$. Eggs laid on the walls of the container were removed every $48 \mathrm{~h}$ by clipping their stalks with scissors. These were then isolated in Petri dishes $(50 \mathrm{~cm}$ diam) to prevent cannibalism by hatching neonates. Larvae were provisioned every $48 \mathrm{~h}$ with ad libitum frozen eggs of Ephestia kuehniella Zeller (Lepidoptera: Pyralidae) obtained from a commercial supplier (Beneficial Insectary, Oak Run, CA, USA), and with water on a piece of sponge until larvae pupated. Emergent adults were transferred to a plastic container (as above) for mating and production of the next generation. 
Seeds of sunflower were planted $2.0 \mathrm{~cm}$ deep in metal trays $(8.0 \mathrm{~cm} \times 51.0 \mathrm{~cm} \times 36.0 \mathrm{~cm})$ filled with a mixture of soil, peat moss and perlite $(1: 1: 1)$ and germinated in a greenhouse at $25.0 \pm 2{ }^{\circ} \mathrm{C}$ under natural light supplemented during daylight hours with metal halide lamps ( $L: D=12: 12)$. Plants were watered daily, but minimally, to avoid excessive leaching of insecticide from treated seeds. Three treatments consisted of 1) seeds of Pioneer 63N82 factory-treated with chlorantraniliprole (Prevathon ${ }^{\circledR}, 1800 \mathrm{mg}$ ai $100 \mathrm{~kg}^{-1}$, DuPont Crop Protection, Wilmington, DE), 2) seeds of Triumph Nusun cv $810 \mathrm{CL}$ sunflower, factory-treated with thiamethoxam (Cruiser 5FS ${ }^{\circledR}, 50 \mathrm{mg}$ ai $100 \mathrm{~kg}^{-1}$, Syngenta Crop Protection, Greensboro, NC), and 3) the same Triumph cultivar without any insecticide (control). Ideally, the same sunflower cultivar would have been employed with both seed treatments, but these are commercially applied by different companies on their own proprietary cultivars. Both cultivars had similar agronomic characteristics (oilseed varieties of normal stature and similar maturity group). Sunflower stalks were harvested beginning at the V2 stage (two true leaves expanded) and every two days thereafter for each period of insect exposure. The V2 stage corresponded to plants 1415 days post-emergence in the greenhouse. The extrafloral nectaries of sunflower are very small and distributed widely over the surface of stems, leaf petioles, and even primary leaf veins. Before provisioning to insects, the ends of excised stem segments (ca $4.0 \mathrm{~cm}$ long) were dipped in liquid paraffin to seal vascular tissues and maintain turgor, while at the same time preventing the exudation of resinous materials that might pose a hazard to the insects.

\section{Exposure of larvae}

In each treatment, first instar larvae of $C$. carnea (neonates within 1-2 h of eclosion) were isolated in Petri dishes (5.0 cm diam) each with a sunflower stem segment (prepared as described above) that was replaced every $48 \mathrm{~h}$ until larvae pupated. A total of 
40 larvae were placed in each treatment, grouped in eight replicates of five for purposes of assessing mortality. Frozen eggs of $E$. kuehniella were provided ad libitum and refreshed every $48 \mathrm{~h}$. Emergent adults were sexed and the maximum number of pairs established in each treatment (control $=16$, chlorantraniliprole $=11$, thiamethoxam $=12$ ). Adult pairs were isolated in plastic cylinders $(5.0 \mathrm{~cm}$ diam $\times 10.0 \mathrm{~cm} \mathrm{ht})$, each sealed with a ventilated plastic lid. Artificial diet (as above) and water on a sponge were provisioned and refreshed every $48 \mathrm{~h}$. Developmental time, larval and pupal survival (black pupae and pharate adults were tallied as dead), sex ratio $(\Sigma+/ \Sigma(++\hat{\jmath}))$, adult survival, preoviposition period (time from adult emergence to first oviposition), and female 10-d fecundity (total eggs laid in ten days of oviposition) were all recorded by examining all replicates daily and harvesting all eggs laid. Egg viability was assessed by harvesting 5 - 10 eggs per female, per treatment, on the fifth day of oviposition and isolating these in Petri dishes $(5.0 \mathrm{~cm})$ until eclosion.

\section{Exposure of adults}

Male and female C. carnea (ca $24 \mathrm{~h}$ old) were paired in plastic cylinders $(5.0 \mathrm{~cm}$ diam x $10.0 \mathrm{~cm}$ ht) sealed with a ventilated plastic lid ( $n=20$ pairs per treatment) for the duration of the entire experiment. Each container had a piece of parafilm with artificial diet and a sunflower stem segment (as above). The insects were exposed to sunflower stems for a period of eight days, and all stems were replaced every $48 \mathrm{~h}$. After this period, pairs were provisioned with water on a sponge and artificial diet refreshed every $48 \mathrm{~h}$. The eggs were counted and removed daily by clipping their pedicels with scissors. To assess the egg viability and offspring fitness, the third and fifth clutches (oviposition days) of each female were collected and the eggs isolated in Petri dishes (5.0 cm diam). Adult survival, preoviposition period, fecundity and egg viability were all scored (as above). After eclosion, 10 larvae from each female were reared and monitored until they emerged as adults. Development time, larval and pupal survival (black pupae and pharate adults were tallied as dead) and sex ratio $\left(\Sigma q / \Sigma\left(\varphi_{+} \delta^{\lambda}\right)\right)$ were all recorded. 


\section{Statistical analysis}

Developmental data from the larval bioassay and reproductive data from the adult bioassay were subjected to one-way ANOVA followed by a Bonferroni test $(\alpha=0.05$ ) to separate means (PROC GLM; SAS Institute 2008). Data obtained from the offspring of exposed adults were analyzed using an independent $t$-test $(\alpha=0.05)$ (PROC TTEST, SAS Institute 2008). Sex ratio was analyzed using the Chi-square Goodness of Fit test $(\alpha=0.05)$ (PROC FREQ; SAS Institute 2008). Adult survival data was submitted to survival analysis using the non-parametric procedure LIFETEST (SAS Institute 2008) which produces survival curves from KaplanMeier estimators. Data from pairs that survived beyond the tenth day of oviposition were censored. Median survival times (LT50) were estimated for treatments in which adult mortality was higher than $50 \%$ and their respective $95 \%$ confidence intervals determined. Fecundity and egg viability data violated ANOVA assumptions of normality and homoscedasticity (PROC UNIVARIATE; SAS Institute 2008) and were $\sqrt{x}$ and arcsine $\sqrt{x}$ transformed, respectively; untransformed means are presented in the tables.

\section{Results}

Larval exposure

There were no significant differences among treatments in larval survival $\left(F_{2,21}=0.42 ; P=0.662\right)$, duration of larval development $\left(F_{2,21}=2.15 ; P=0.141\right)$, pupal survival $\left(F_{2,21}=0.53 ; P=0.597\right)$ or duration of pupal development $\left(F_{2,21}=0.12 ; P=0.884\right)($ Table 1$)$. The sex ratio (proportion female) was reduced by thiamethoxam relative to chlorantriniliprole $\left(\chi^{2}=8.40 ;\right.$ d.f. $=2 ; P=0.015$ ); 
although neither treatment was significantly different from controls, the power of the test was likely limited by sample sizes. The survival of the resulting adults was unaffected by any treatment (log-rank test, $\chi^{2}=2.39$; $\left.\mathrm{df}=2 ; P=0.303\right)($ Fig $1 \mathrm{~A})$; neither was the preoviposition period $\left(F_{2,35}=0.50 ; P=0.608\right)$, fecundity $\left(F_{2,35}=0.55 ; P=0.582\right)$ or egg viability $\left(F_{2,31}=0.02 ; P=0.983\right)($ Table 1$)$. No treatment caused mortality of adults higher than $50 \%$, so LT50 values were not computed.

Adult exposure

Adults of $C$. carnea exposed to sunflower stems grown from treated seeds had significantly lower survival in both chlorantraniliprole and thiamethoxam treatments than in controls (log-rank test, $\chi^{2}=11.35$; $\mathrm{df}=2 ; P=0.003$ ) (Fig $1 \mathrm{~B}$ ) and median survival times ( $\left.\mathrm{LT}_{50}\right)$ were lower in the thiamethoxam treatment than in the chlorantraniliprole treatment (Fig 2). LT50 was not computed for control insects because mortality was $<50 \%$. Only 11, 10 and 7 females out of 20 oviposited in the control, chlorantraniliprole and thiamethoxam treatments, respectively, and the fecundity of these females was reduced by both insecticide treatments relative to controls $\left(F_{2,25}=7.05 ; P=0.004\right.$; Table 2$)$. Too few eggs were obtained in the thiamethoxam treatment to monitor development of offspring. The chorantraniliprole treatment significantly reduced the survival of offspring produced by exposed adults $(t=2.59 ; \mathrm{df}=$ 8; $P=0.031)$, but other development parameters of offspring remained unaffected; egg viability $(t=0.47 ; \mathrm{df}=10 ; P=0.650)$, duration of larval development $(t=-1.02 ; \mathrm{df}=8 ; P=0.337)$, pupal survival $(100 \%)$, pupal duration $(t=0.86 ; \mathrm{df}=8 ; P=0.031)$ and sex ratio $\left(\chi^{2}=0.39 ; \mathrm{df}=1 ; P=0.533\right)$ (Table 2$)$.

\section{Discussion}


The present study confirms that diamides and neonicotinoids, when used as seed treatments, can adversely affect certain nontarget organisms that come into contact with seedling plants. Both chlorantraniliprole and thiamethoxam caused lethal and sublethal effects to $C$. carnea adults exposed to sunflower stems grown from treated seeds. However, thiamethoxam demonstrated higher toxicity than chlorantraniliprole and greater negative impacts on survival, fecundity and LT50. The most likely explanation for these results is the contamination of extrafloral nectar with residues of the insecticides, since these insects lack chewing mouthparts and are unable to consume leaf or stem tissues, but were often directly observed consuming nectar. Both adults and larvae of $C$. carnea are known to consume extrafloral nectar to supplement their diet (Limburg and Rosenheim 2001; Rogers et al. 2007). The effects on reproductive parameters observed in the present work suggest that populations of $C$. carnea might be reduced in sunflower fields when seed is treated with chlorantraniliprole or thiamethoxam. This is a significant agroecological finding because sunflower extrafloral nectar is an important source of hydration and nutrition for a wide range of beneficial insects during the hot, dry summers on the Great Plains when little free moisture is available (Michaud and Qureshi 2006). For example, the presence of sunflowers has been shown to improve the area-wide survival of natural enemy species important in the biological control of key pests in neighboring crops such as wheat, i.e. Diuraphis noxia (Mordvilko) (Hemiptera: Aphididae) (Brewer et al. 2008).

Although not quantified in these experiments, we observed that the water demand of adults appeared to be much greater than that of larvae. This becomes visually evident if the water supply is not maintained. Whereas larvae do not require a supplementary water source to develop successfully, adults quickly desiccate in the absence of moisture, their abdomens becoming visibly shrivelled. This was evident to some degree in all treatments of adults after the exposure period, during which the sunflower stem segments were the only, and likely insufficient, source of hydration; adult hydration recovery, characterized by visible re-inflation of the abdomen, was clearly evident within $24 \mathrm{~h}$ of provision of free water. We hypothesize that dehydration during the exposure period is the likely cause of greater female infertility, longer pre-oviposition periods and lower fecundities 
following adult exposure compared to larval exposure (Table 1 vs Table 2). Therefore, the high water demand of adults likely drove greater consumption of extrafloral nectar relative to larvae, which likely consume it primarily for its sugar content.

Because extrafloral nectar lacks the protein needed for growth and development, its consumption by lacewing larvae tends to decrease with increasing availability of prey (Limburg and Rosenheim 2001). Thus, the availability of ad libitum prey (eggs of $E$. kuehniella) during larval exposure in these experiments may have somewhat reduced the consumption of extrafloral nectar by larvae. If so, our results may underestimate the potential impact on larvae of extrafloral nectar contaminated with these materials when prey is scarce. Also, it could be argued that some effects observed in the thiamethoxam treatment may be attributable to the Pioneer 63 N82 cultivar itself, since the controls were Triumph $810 \mathrm{CL}$, but this is unlikely in our view.

Cloyd and Bethke (2011) reviewed the various potential routes of exposure to neonicotinoid insecticides for beneficial insects in interior plantscapes, including floral nectar, and emphasized the importance of plant species and age as factors influencing concentrations. Residues of neonicotinoids used in seed treatments have been detected in the nectar and pollen of rapeseed, corn and sunflower at concentrations from 20 to 39 ppb in pollen (Cutler and Scott-Dupree 2007; Krupke et al. 2012) and from 22 ppb to 30 ppb in nectar (Bonmatin et al. 2005; Cutler and Scott-Dupree 2007). However, floral nectar and pollen are produced by mature plants in late stages of reproduction and, given the role of plant age in diluting the concentration of insecticide in plant tissues, concentrations are likely much greater in the extrafloral nectar of younger plants, such as those provided in this study.

Seagraves and Lundgren (2012) found reduced numbers of adult natural enemies, e.g., Chrysoperla sp and Nabis americoferus Carayon (Hemiptera: Nabidae), in soybean fields grown from neonicotinoid-treated seed. When applied as a soil drench, imidacloprid reduced the survival of adults of C. carnea (Rogers et al. 2007) and the parasitoid Anagyrus pseudococci (Girault) (Hymenoptera: Encyrtidae) that fed on flowers of Fagopyrum esculentum (Polygonaceae) (Krischik et al. 2007). 
Effects of chlorantraniliprole on lacewings have been recorded in other studies Amarasekare and Shearer (2013) found that chlorantraniliprole was highly toxic to adults and larvae of $C$. carnea and $C$. johnsoni when the predator ingested contaminated diet or prey. Topical application of chlorantraniliprole on larvae of C. externa did not cause negative effects (Zotti et al. 2013), as this material must be ingested to reach its active sites. For example, Smagghe et al. (2013) found negative effects on reproduction when Bombus terrestris (L) (Hymenoptera: Apidae) fed on pollen contaminated with chlorantraniliprole. However,

chlorantraniliprole was considered safe for Macrolophus pygmaeus (Rambur) (Hemiptera: Miridae) when exposed to the insecticide via direct, residual and oral routes (Martinou et al. 2014). Similarly, no significant contact toxicity of chlorantraniliprole, either in terms of lethal or sublethal effects, was recorded on the anthocorid predator Orius laevigatus (Fieber) (Biondi et al. 2012b). Thus, the toxicity of chlorantraniliprole for beneficial insects may depend on both the species tested and the route of exposure.

The high toxicity of thiamethoxam to $C$. carnea in the present study compared to chlorantraniliprole may be related to its high mobility in phloem elements and its non-acidic nature (Nauen et al. 1999; Buchholz and Nauen 2002). Lanka et al. (2014) studied rice plants grown from treated seed and found concentrations of thiamethoxam four-fold greater in above-ground tissues than in the roots. In contrast, chlorantraniliprole concentrations in rice roots were up to ten times higher than those in above-ground parts. This demonstrates the high mobility of thiamethoxam in plant tissues, which can result in contamination of pollen, floral and extrafloral nectar. Furthermore, the conversion of thiamethoxam into highly toxic metabolites such as clothianidin (Casida 2011) may contribute to increased toxicity to insects, including natural enemies. Nauen et al. (2003) demonstrated that clothianidin is one of the primary metabolites of thiamethoxam in true leaves of cotton plants treated via soil drench. These authors inferred that clothianidin, not thiamethoxam, was responsible for toxicity of thiamethoxam-treated leaf disks to Spodoptera frugiperda (Smith) (Lepidoptera: Noctuidae) larvae. However, its greater lipophilicity and lower solubility in water make clothianidin less likely than thiamethoxam to contaminate nectar. 
In summary, both chlorantraniliprole and thiamethoxam caused negative effects on the survival and reproduction $C$. carnea adults and the survival of their progeny when the adults were exposed to seedlings grown from seeds treated with these insecticides. In companion studies on the same pesticides identically applied as sunflower seed treatments, no direct mortality was observed on adults of the braconid wasp Lysiphlebus testaceipes (Cresson), although various sublethal effects on its behavior and biological performance were recorded (Moscardini et al. 2014). Moreover, both lethal and sublethal effects were caused by thiamethoxam and only sublethal effets by chlorantraniliprole on nymphs and adults of the anthocorid predator Orius insidiosus (Say) (Gontijo et al. 2014). The treatment of seeds with systemic insecticides is convenient for farmers and profitable for seed companies. However, seed treatment as an 'insurance policy' without identification of a target pest runs counter to the basic principles of IPM.

The results of the present study and others cited above are converging toward a conclusion that systemic insecticides used as seed treatments can cause negative effects on beneficial organisms, potentially disrupting their population dynamics, and should not be assumed compatible with biological control and IPM simply because their mode of application limits direct exposure of nontarget insects and reduces overall environmental exposure to the material compared to broadcast applications. More research is warranted to assess the toxicity of systemic insecticides applied as seed treatments in commercial sunflower seed and other crops. These studies should evaluate the concentration of insecticide in different developmental stages of the plant and in different plant parts, taking into account the distinct biology and behavior of different beneficial species in different life stages, both in the presence and absence of prey. The use of systemic insecticides in the treatment of sunflower seeds may be justified in specific contexts, but further investigation is required to determine the long-term compatibility of this approach with IPM programs that rely on conservation biological control of significant pests. 
Acknowledgments The authors are grateful to the CAPES Foundation (Brazilian Ministry of Education), the National Council of Scientific and Technological Development (CNPq), and the Minas Gerais State Foundation for Research Aid (FAPEMIG) for scholarship support from CAPES - no 3363-13-9 (PCG) and CAPES - no 3362-13-2 (VFM). This is contribution no. 14-294 of the Kansas State Experiment Station.

\section{References}

Albajes R, López C, Pons X (2003) Predatory fauna in cornfields and response to imidacloprid seed treatment. J Econ Entomol 96:1805-1813

Albuquerque GS, Tauber CA, Tauber MJ (1994) Chrysoperla externa (Neuroptera: Chrysopidae): life history and potential for biological control in Central and South America. Biol Control 4:8-13

Amarasekare KG, Shearer PW (2013) Comparing effects of Insecticides on two green lacewing species, Chrysoperla johnsoni and Chrysoperla carnea (Neuroptera: Chrysopidae). J Econ Entomol 106:1126-1133

Benzidane Y, Touinsi S, Motte E, Jadas-Hecart A, Communal PY, Leduc L, Thany SH (2010) Effect of thiamethoxam on cockroach locomotor activity is associated with its metabolite clothianidin. Pest Manag Sci 66:1351-1359

Biondi A, Mommaerts V, Smagghe G, Viñuela E, Zappalà L, Desneux N (2012a) The non-target impact of spinosyns on beneficial arthropods. Pest Manag Sci 68:1523-1536

Biondi A, Desneux N, Siscaro G, Zappalà L (2012b) Using organic-certified rather than synthetic pesticides may not be safer for biological control agents: selectivity and side effects of 14 pesticides on the predator Orius laevigatus. Chemosphere 87:803812 
Biondi A, Zappalà L, Stark JD, Desneux N (2013) Do biopesticides affect the demographic traits of a parasitoid wasp and its biocontrol services through sublethal effects? PlosOne 8(9):e76548

Bonmatin JM, Marchand PA, Charvet R, Moineau I, Bengsch ER, Colin AE (2005) Quantification of imidacloprid uptake in maize crops. J Agric Food Chem 53:5336-5341

Bradshaw JD, Rice ME, Hill JH (2008) Evaluation of management strategies for bean leaf beetles (Coleoptera: Chrysomelidae) and bean pod mottle virus (Comoviridae) in soybean. J Econ Entomol 101:1211-1227

Brewer MJ, Noma T, Elliott NC, Kravchenko AN, Hild AL (2008) A landscape view of cereal aphid parasitoid dynamics reveals sensitivity to farm- and region-scale vegetation structure. Eur J Entomol 105:503-511

Buchholz A, Nauen R (2002) Translocation and translaminar bioavailability of two neonicotinoid insecticides after foliar application to cabbage and cotton. Pest Manag Sci 58:10-16

Casida JE (2011) Neonicotinoid metabolism: compounds, substituents, pathways, enzymes, organisms, and relevance. J Agric Food Chem 59:2923-2931

Choate BA, Lundgren JG (2013) Why eat extrafloral nectar? Understanding food selection by Coleomegilla maculata (Coleoptera: Coccinellidae). BioControl 58:359-367

Cloyd RA, Bethke JA (2011) Impact of neonicotinoid insecticides on natural enemies in greenhouse and interiorscape environments. Pest Manag Sci 67:3-9

Cutler GC, Scott-Dupree CD (2007) Exposure to clothianidin seed-treated canola has no long-term impact on honey bees. J Econ Entomol 100:765-772

Desneux N, Decourtye A, Delpuech JM (2007) The sublethal effects of pesticides on beneficial organisms. Annu Rev Entomol 52:81-106 
Dively GP, Kamel A (2012) Insecticide residues in pollen and nectar of a cucurbit crop and their potential exposure to pollinators. J Agric Food Chem 60:4449-4456

Downes JA (1974) Sugar feeding by larva of Chrysopa (Neuroptera). Can Entomol 106:121-125

Easton AH, Goulson D (2013) The neonicotinoid insecticide imidacloprid repels pollinating flies and beetles at field-realistic concentrations. PLoS One 8:e54819

Gontijo PC, Moscardini VF, Michaud JP, Carvalho GA (2014) Non-target effects of two sunflower seed treatments on Orius insidiosus (Hemiptera: Anthocoridae). Pest Manag Sci DOI 10.1002/ps.3798

Goulson D (2013) REVIEW: An overview of the environmental risks posed by neonicotinoid insecticides. J Appl Ecol 50:977-987

Gurr GM, Scarratt SL, Wratten SD, Berndt L, Irvin NA (2004) Ecological engineering, habitat manipulation and pest management. In: Gurr GM, Wratten SD, Altieri MA (ed) Ecological Engineering for Pest Management. Comstock Press, Ithaca, pp 1-12

Hagen KS (1986) Ecosystem analysis: plant cultivars (HPR), entomophagous species and food supplements. In: Boethel DJ, Eikenbarrey RD (ed) Interactions of plant resistance and prasitoids and predators of insects. Wiley, New York, pp 151-197

He YX, Zhao JW, Zheng Y, Desneux N, Wu K (2012) Lethal effect of imidacloprid on the coccinellid predator Serangium japonicum and sublethal effects on predator voracity and on functional response to the whitefly Bemisia tabaci. Ecotoxicology 21: 12911300

Hull L, Beers E (1985) Ecological selectivity: modifying chemical control practices to preserve natural enemies. In: Hoy MA, Herzog DC (ed) Biological control in agricultural IPM systems. Academic Press, New York, pp 103-122

Krischik VA, Landmark AL, Heimpel GE (2007) Soil-applied imidacloprid is translocated to nectar and kills nectar-feeding Anagyrus pseudococci (Girault) (Hymenoptera: Encyrtidae). Environ Entomol 36:1238-1245

Krupke CH, Hunt GJ, Eitzer BD, Andino G, Given K (2012) Multiple routes of pesticide exposure for honey bees living near agricultural fields. PLoS One 7:e29268 
Lahm GP, Cordova D, Barry JD (2009) New and selective ryanodine receptor activators for insect control. Bioorgan Med Chem 17:4127-4133

Lahm GP, Stevenson TM, Selby TP, Freudenberger JH, Cordova D, Flexner L, Bellin CA, Dubas CM, Smith BK, Hughes KA, Hollingshaus JG, Clark CE, Benner EA (2007) Rynaxypyr: a new insecticidal anthranilic diamide that acts as a potent and selective ryanodine receptor activator. Bioorgan Med Chem Lett 17:6274-6279

Lanka SK, Stout MJ, Beuzelin JM, Ottea JA (2014) Activity of chlorantraniliprole and thiamethoxam seed treatments on life stages of the rice water weevil as affected by the distribution of insecticides in rice plants. Pest Manag Sci 70:338-344

Laurent FM, Rathahao E (2003) Distribution of C-14 imidacloprid in sunflowers (Helianthus annuus L) following seed treatment. J Agr Food Chem 51:8005-8010

Li X, Degain BA, Harpold VS, Marcon PG, Nichols RL, Fournier AJ, Naranjo SE, Palumbo JC, Ellsworth PC (2012) Baseline susceptibilities of B- and Q-biotype Bemisia tabaci to anthranilic diamides in Arizona. Pest Manag Sci 68:83-91

Limburg DD, Rosenheim JA (2001) Extrafloral nectar consumption and its influence on survival and development of an omnivorous predator, larval Chrysoperla plorabunda (Neuroptera: Chrysopidae). Environ Entomol 30:595-604

Lundgren JG (2009) Relationships of natural enemies and non-prey foods. Springer International, Dordrecht, The Netherlands

Martinou AF, Seraphides N, Stavrinides MC (2014) Lethal and behavioral effects of pesticides on the insect predator Macrolophus pygmaeus. Chemosphere 96:167-173

Michaud JP, Qureshi JA (2006) Reproductive diapause in Hippodamia convergens (Coleoptera: Coccinellidae) and its life history consequences. Biol Control 39:193-200

Moscardini VF, Gontijo PC, Michaud JP, Carvalho GA (2014) Sublethal effects of chlorantraniliprole and thiamethoxam seed treatments when Lysiphlebus testaceipes feed on sunflower extrafloral nectar. BioControl DOI 10.1007/s10526-014-9588-5 
Nauen R, Ebbinghaus-Kintscher U, Salgado VL, Kaussmann M (2003) Thiamethoxam is a neonicotinoid precursor converted to clothianidin in insects and plants. Pestic Biochem Phys 76:55-69

Nauen R, Reckmann U, Armborst S, Stupp HP, Elbert A (1999) Whitefly-active metabolites of imidacloprid: biological efficacy and translocation in cotton plants. Pestic Sci 55:265-271

New TR (1975) The biology of Chrysopidae and Hemerobiidae (Neuroptera), with reference to their usage as biocontrol agents: a review. Trans R Entomol Soc Lond 127:115-140

Ohkawara Y, Akayama A, Matsuda K, Andersch W (2002) Clothianidin: a novel broad spectrum neonicotinoid insecticide. In: Proc Brighton Crop Protection Conference (ed) Pests and Diseases. Brighton, UK, pp 51-58

Pappas ML, Broufas GD, Koveos DS (2011) Chrysopid predators and their role in biological control. J Entomol 8:301-326

Patt JM, Wainright SC, Hamilton GC, Whittinghill D, Bosley K, Dietrick J, Lashomb JH (2003) Assimilation of carbon and nitrogen from pollen and nectar by a predaceous larva and its effects on growth and development. Ecol Entomol 28:717-728

Planes L, Catalán J, Tena A, Porcuna JL, Jacas JA, Izquierdo J., Urbaneja A (2013) Lethal and sublethal effects of spirotetramat on the mealybug destroyer, Cryptolaemus montrouzieri. J P Sci 86:321-327

Principi MM, Canard M (1984) Feeding habits. In: Canard M, Semeria Y, New TR (ed) Biology of Chrysopidae. The Hague, pp 7692

Rogers MA, Krischik VA, Martin LA (2007) Effect of soil application of imidacloprid on survival of adult green lacewing, Chrysoperla carnea (Neuroptera: Chrysopidae), used for biological control in greenhouse. Biol Control 42:172-177

Royer TA, Walgenbach DD (1991) Predacious arthropods of cultivated sunflower in eastern South Dakota. J Kans Entomol Soc 64:112-116

Sanchez-Bayo F, Tennekes HA, Goka K (2013) Impact of systemic insecticides on organisms and ecosystems. In: Trdan S (ed) Insecticides - development of safer and more effective technologies. InTech, Croatia, pp 365-414 
SAS Institute (2008) SAS for Windows Version 90 SAS. Institute Cary, North Carolina, USA

Schwarz M, Christie D, Andersch W, Kemper K, Fellmann K, Altmann R (2002) Control of corn rootworms (Diabrotica spp) and of secondary pests of corn (Zea mays) using seed treatment of clothianidin. In: Proc Brighton Crop Protection Conference (ed) Pests and Diseases. Brighton, UK, pp 59-64

Seagraves MP, Lundgren JG (2012) Effects of neonicitinoid seed treatments on soybean aphid and its natural enemies. J Pest Sci 85:125-132

Smagghe G, Deknopper J, Meeus I, Mommaerts V (2013) Dietary chlorantraniliprole suppresses reproduction in worker bumblebees. Pest Manag Sci 69:787-791

Stelzla M, Devetak D (1999) Neuroptera in agricultural ecosystems. Agric Ecosyst Environ 74:305-321

Stoner KA, Eitzer BD (2012) Movement of soil-applied imidacloprid and thiamethoxam into nectar and pollen of squash (Cucurbita pepo). PLoS One 7:e39114

Strausbaugh CA, Eujayl IA, Foote P (2010) Seed treatments for the control of insects and diseases in sugarbeet. J Sug Beet Res 47:105-125

Tomizawa M, Casida JE (2005) Neonicotinoid insecticide toxicology: mechanisms of selective action. Annu Rev Pharmacol 45:247268

Venzon M, Rosado MC, Euzébio DE, Souza B, Schoereder JH (2006) Suitability of leguminous cover crop pollens as food source for the green lacewing Chrysoperla externa (Hagen) (Neuroptera: Chrysopidae). Neotrop Entomol 35:371-376

Wackers FL, Romeis J, van Rijn P (2007) Nectar and pollen feeding by insect herbivores and implications for multitrophic interactions. Annu Rev Entomol 52:301-323

Zotti JM, Grutzmacher AD, Lopes IH, Smagghe G (2013) Comparative effects of insecticides with different mechanisms of action on Chrysoperla externa (Neuroptera: Chrysopidae): lethal, sublethal and dose-response effects. Insect Sci 20:743-752 
Table 1. Mean ( \pm SE) survival, developmental time and sex ratio (proportion female) of Chrysoperla carnea larvae when exposed to sunflower stems grown from treated seeds, and their subsequent reproductive parameters.

\begin{tabular}{|c|c|c|c|c|c|c|c|c|}
\hline \multirow{3}{*}{$\begin{array}{l}\text { Treatment } \\
\text { Control }\end{array}$} & \multicolumn{2}{|c|}{ Larval period $^{1}$} & \multicolumn{2}{|c|}{ Pupal period ${ }^{1}$} & \multirow{2}{*}{$\begin{array}{c}\text { Sex ratio }{ }^{2} \\
(n)\end{array}$} & \multicolumn{3}{|c|}{ Reproductive parameters $^{1}(\mathrm{n})$} \\
\hline & \multirow{2}{*}{$\begin{array}{l}\text { Survival }^{*}(\%) \\
97.5 \pm 2.50\end{array}$} & \multirow{2}{*}{$\begin{array}{l}\text { Duration }(d) \\
8.9 \pm 0.13\end{array}$} & \multicolumn{2}{|c|}{ Survival $^{* *}(\%)$ Duration (d) } & & $\begin{array}{l}\text { Preoviposition } \\
\text { period (d) }\end{array}$ & $\begin{array}{l}\text { 10-d fecundity } \\
\left.\text { (eggs female }{ }^{-1}\right)\end{array}$ & $\begin{array}{l}\text { Egg viability } \\
\text { (\% eclosing) }\end{array}$ \\
\hline & & & $85.0 \pm 5.00$ & $9.1 \pm 0.03$ & $0.46 \mathrm{ab}(33)$ & $6.7 \pm 0.51(16)$ & $105.4 \pm 10.62$ & $93.1 \pm 3.22$ \\
\hline Thiamethoxam & $92.5 \pm 5.26$ & $8.7 \pm 0.10$ & $92.5 \pm 5.26$ & $9.0 \pm 0.05$ & 0.36 b (33) & $6.3 \pm 0.38(12)$ & $93.3 \pm 8.38$ & $92.2 \pm 6.62$ \\
\hline
\end{tabular}

Analysis by one-way ANOVA $\left({ }^{1}\right)$ or Chi-square $\left({ }^{2}\right)$.

Means followed by different letters were significantly different within columns (Chi-square, $\alpha=0.05$ ).

*Percentage of neonate larvae ( $n=40 /$ treatment) yielding pupae.

${ }^{\star *}$ Percentage of pupae yielding viable adults. 
Table 2. Mean ( \pm SE) reproductive parameters of Chrysoperla carnea adult pairs exposed to sunflower stems grown from treated seed and the developmental parameters of their offspring.

\begin{tabular}{|c|c|c|c|c|c|c|c|c|}
\hline \multirow{2}{*}{ Treatment } & \multicolumn{3}{|c|}{ Reproductive parameters ${ }^{1,2}$} & \multicolumn{2}{|c|}{ Larval period $^{2}$} & \multicolumn{2}{|c|}{ Pupal period² } & \multirow{2}{*}{$\begin{array}{c}\text { Sex } \\
\text { ratio } \\
\text { (n) }\end{array}$} \\
\hline & $\begin{array}{l}\text { Preoviposition } \\
\text { period }(d)\end{array}$ & $\begin{array}{l}\text { 10-d fecundity } \\
(\text { eggs female-1) }\end{array}$ & $\begin{array}{l}\text { Egg viability } \\
\text { (\% eclosing) }\end{array}$ & Survival $^{*}(\%)$ & Duration (d) & $\begin{array}{l}\text { Survival** } \\
\qquad \%)\end{array}$ & Duration (d) & \\
\hline Control & $13.9 \pm 0.75$ & $73.3 \pm 11.77 \mathrm{a}$ & $83.8 \pm 12.23$ & $97.1 \pm 1.84 \mathrm{a}$ & $9.3 \pm 0.15$ & 100 & $9.2 \pm 0.09$ & $0.61(66)$ \\
\hline Chlorantraniliprole & $15.5 \pm 1.03$ & $46.2 \pm 14.76 b$ & $72.5 \pm 24.28$ & $73.3 \pm 10.53 b$ & $9.7 \pm 0.44$ & 100 & $9.1 \pm 0.04$ & $0.54(22)$ \\
\hline Thiamethoxam & $16.4 \pm 1.48$ & $15.1 \pm 9.41 \mathrm{c}$ & - & - & - & - & - & - \\
\hline
\end{tabular}

Analysis by one-way ANOVA (1); t-test $\left({ }^{2}\right)$ or Chi-square $\left({ }^{3}\right)$.

Means followed by different letters were significantly different within columns (Bonferroni or $t$-test, $\alpha=0.05$ ).

Fecundity in the thiamethoxam treatment was too low to permit analysis of offspring development - dashes indicate no data.

*Percentage of neonate larvae producing pupae.

**Percentage of pupae producing viable adults. 


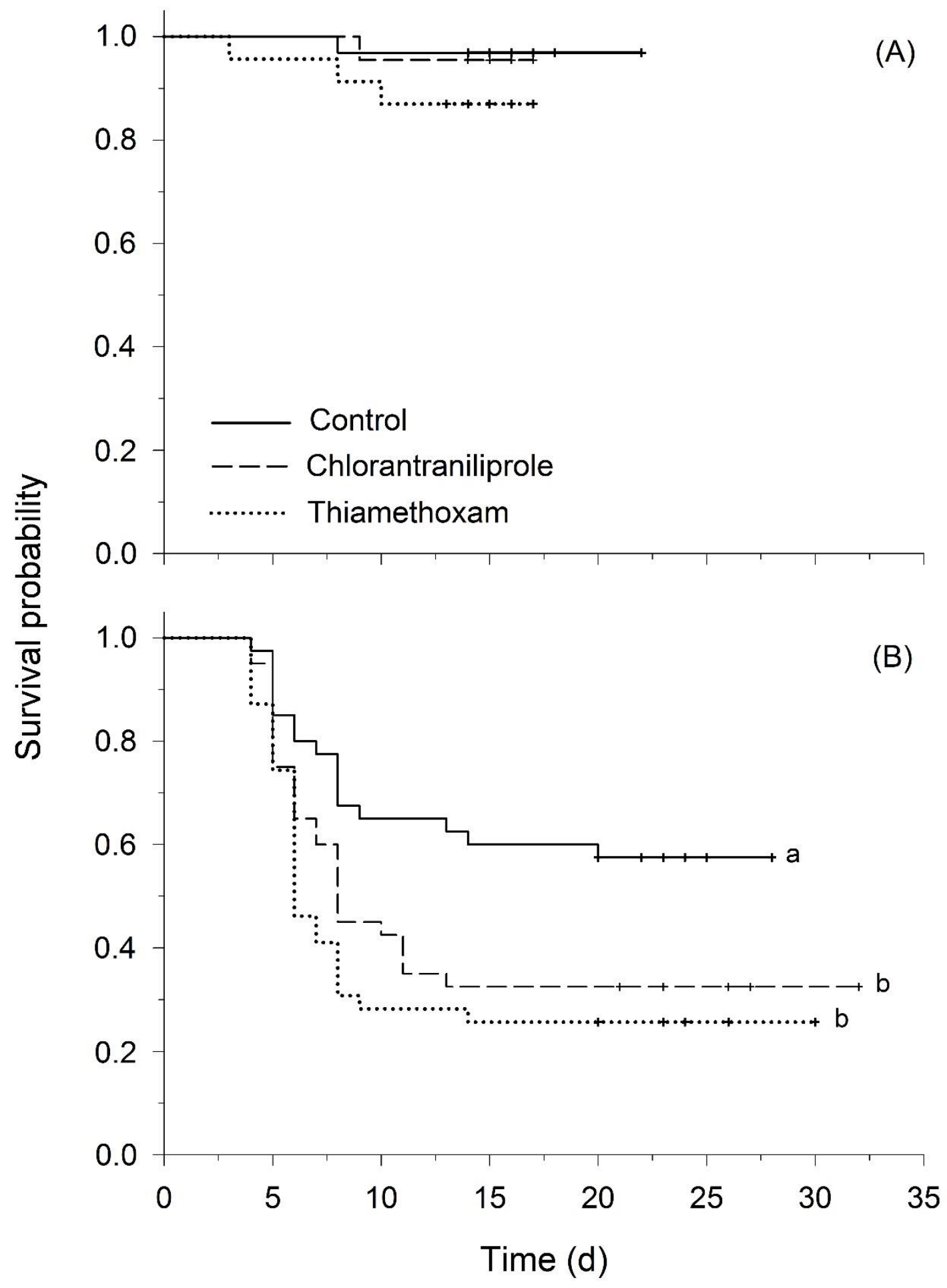

Fig. 1. Survival plots for adult Chrysoperla carnea exposed as larvae (A) and adults (B) to stems of sunflower plants grown from seed treated with either chlorantraniliprole or thiamethoxam. All data were considered (+ censored data). Curves bearing different letters were significantly different (log-rank test, $\alpha=0.05$ ). 


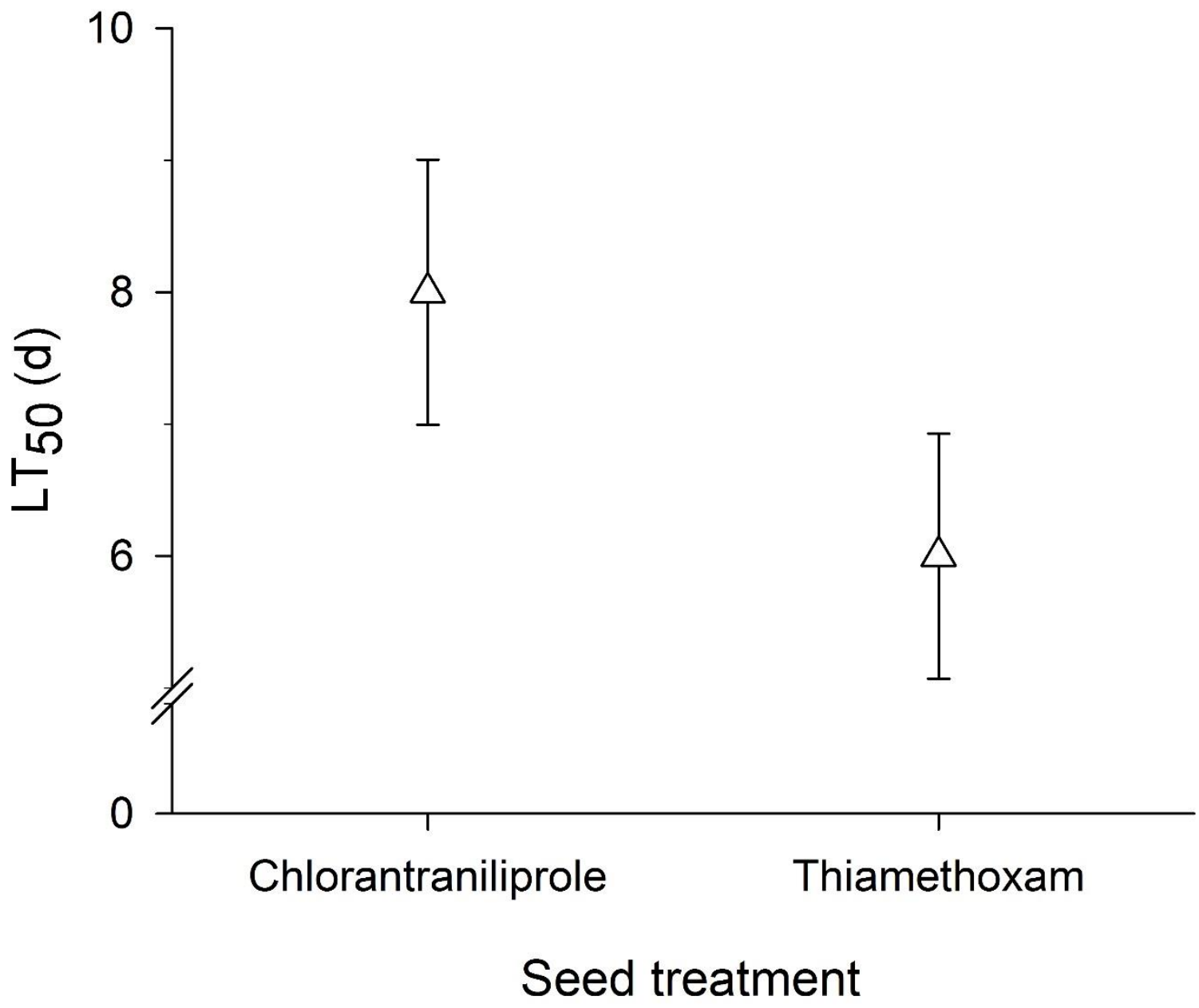

Fig. 2. Median ( $\pm 95 \%$ confidence intervals) survival times $\left(L T_{50}\right)$ for adult Chrysoperla carnea exposed to stems of sunflower plants grown from seed treated with either chlorantraniliprole or thiamethoxam. 